Available online at GSC Online Press Directory

GSC Biological and Pharmaceutical Sciences

e-ISSN: 2581-3250, CODEN (USA): GBPSC2

Journal homepage: https://www.gsconlinepress.com/journals/gscbps

(REVIEW ARTICLE)

\title{
Current status and prospects of the use of biofungicides against plant diseases
}

\author{
Albert Akhmedovich Khakimov ${ }^{1,}{ }^{*}$, Alisher Urazalievich Omonlikov ${ }^{2}$, Samad Bobomurod Ugli Utaganov ${ }^{3}$ \\ ${ }^{1}$ PhD, Associate Professor of the Department of Agrobiotechnology, Tashkent State Agrarian University, Tashkent, \\ Uzbekistan. \\ 2 Doctoral Student (PhD), Assistant of the Department of Agrobiotechnology, Tashkent State Agrarian University, \\ Tashkent, Uzbekistan. \\ ${ }^{3}$ Doctoral student (PhD), Plant Quarantine Research Center, Tashkent, Uzbekistan.
}

Publication history: Received on 04 December 2020; revised on 13 December 2020; accepted on 15 December 2020

Article DOI: https://doi.org/10.30574/gscbps.2020.13.3.0403

\begin{abstract}
Plant pathogenic microorganisms cause great damage to the yield of agricultural crops and also reduce their commercial quality. This article highlights information on the level of damage caused to agricultural crops by pests, as well as the development of organic agriculture, which in recent years has received great attention in many developed countries. In addition, the data from literature were analyzed on the current state and problems of production of pesticides in the world and their use in agriculture, the use of biofungicides against plant diseases. The importance of synthetic pesticides, as well as, controlling the use of synthetic fungicides, and the use of alternative biofungicides in their replacement were also revealed. The article concludes on the need for public reforms and the role of systematic scientific research in creating a local biopesticides market.
\end{abstract}

Keywords: plant diseases, pesticides, synthetic fungicides, biopesticides, biofungicides, antagonistic microorganisms, Trichoderma, Bacillus

\section{Introduction}

The demand for food in the world is increasing due to the raising number of population in the world. This, in its turn, imposes specific, important tasks on the agricultural sector and related sectors, and requires the proper integration of science, education and production.

According to the data of Food and Agriculture Organization of the United Nations (FA0), 80\% of human food is made up of plant products, and the world's annual agricultural trade turnover is \$1,6 trillion, the bulk of which, $82 \%$ of them are food products [1]. In 2018, the Food and Agriculture Organization (FAO) declared the year 2020 as "International Year of Plant Health" in one of its events. The goal of this decision was to engage the world community's attention in the importance of eradicating hunger, reducing poverty, protecting human health and the environment, and maintaining plant health for economic development [2].

Plants are constantly and very seriously stressed by pests and diseases. According to the data of Secretariat of the International Plant Protection Convention (IPPC) at the FAO, if no timely action is taken against pests, this situation can lead to tragic and difficult consequences. Today, from $20 \%$ to $40 \%$ of the crop is lost due to pests and diseases [3], and the amount of this loss makes $14,1 \%$ due to plant diseases, accounting for $\$ 220$ billion in annual sales of agricultural products (Table 1) [4].

\footnotetext{
* Corresponding author: Albert Akhmedovich Khakimov

Department of Agrobiotechnology, Tashkent State Agrarian University, Tashkent, Uzbekistan. 
Table 1 Estimated Annual Crop Losses Worldwide*

\begin{tabular}{lll}
\hline 1 & Attainable crop production (2002 prices) & $\$ 1.5$ trillion \\
\hline 2 & Actual crop production (-36.5\%) & $\$ 950$ billion \\
\hline 3 & Production without crop protection & $\$ 455$ billion \\
\hline 4 & Losses prevented by crop protection & $\$ 415$ billion \\
\hline 5 & Actual annual losses to world crop production & $\$ 550$ billion \\
\hline 6 & Losses caused by diseases only (14.1\%) & $\$ 220$ billion
\end{tabular}

In recent years, "Organic agriculture" has gained great attention worldwide, and according to the Research Institute of Organic Agriculture (FiBL) and the International Federation of Organic Agricultural Movements (IFOAM), the area under organic farming in the world has been growing steadily and over the next 20 years, its area increased almost 6 times, having reached 69,8 million hectares in 2017 (Fig. 1). The bulk of this amount relates to Australia (51\%) and EU countries (21\%) (Fig. 2) [5].

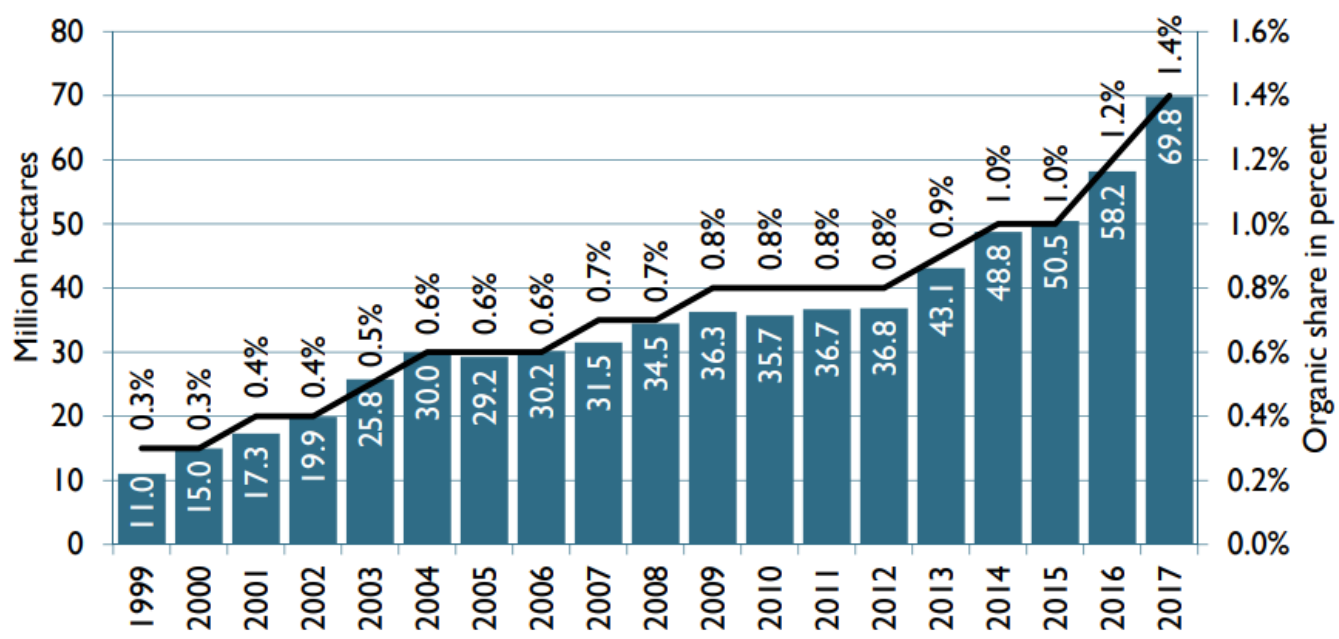

Figure 1 Growth of the organic agricultural land and organic share 1999-2017.

(Source: FiBL-IFOAM-SOEL surveys 1999-2019)

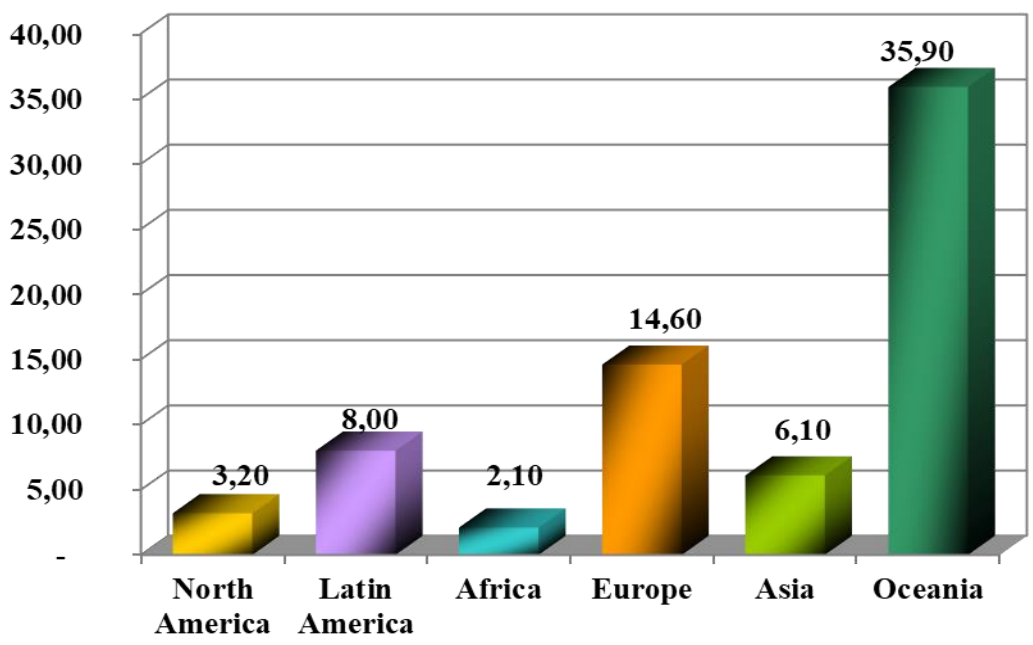

Figure 2 Organic farmland, 2017, million ha (Source: FiBL, 2019) 
The term "Organic agriculture" has a number of definitions that mostly refers to a system for crops, livestock and fish farming emphasizing environmental protection and the use of natural farming techniques. It is not intended for use of external farming resources, but for control of ecosystem. For the replacement of above-mentioned external resources of agriculture, special methods and means are used to increase soil fertility or to prevent the development of pests and diseases. It is concerned not only with the end-product, but with the entire system used to produce and deliver the agricultural product. To this end, the entire farm cycle, from production and processing, to handling and delivery, excludes the use of artificial products such as genetically modified organisms and certain external agricultural inputs such as pesticides, veterinary drugs, additives and fertilizers. "Organic agriculture" - is an entire eco-system that supports biodiversity, biological activity of plants and soil, free from pesticides and synthetic fertilizers, as well as controls production process. Organic farmers rely instead on natural farming methods and modern scientific ecological knowledge in order to maximize the long-term health and productivity of the ecosystem, enhance the quality of the products and protect the environment. Proponents of organic methods believe that it is a more sustainable and less damaging approach to agriculture [6].

One of the main conditions of organic agriculture is the non-use or reduction of the use of pesticides against pests, as well as the introduction of the use of biological agents against these pests instead. This, in turn, will be the basis for obtaining an ecologically pure product that is free of pesticides. Therefore, the use of biological fungicides, bioinsecticides and biologically active substances in the protection of agricultural crops from pests is one of the most pressing issues of today.

\section{Worldwide pesticides production and use in agriculture}

Pesticides are natural and synthetic chemicals used against plant pests, diseases and weeds. Pesticides may include herbicides, insecticides, fungicides, rodenticides, nematicides, and others. In the process of agricultural development, pesticides have become a vital means of plant protection in increasing crop yields [7].

Nowadays, the global production and using rate of pesticides is 3,5 million tons [8, 9], and according to the FA0, in 2018 it was 4,1 million tons. Of this amount, 1,2 million tons were herbicides, 0,53 million tons were fungicides and bactericides, and 0,4 million tons were insecticides [10]. The average application of pesticides per hectare of cropland in 2017 was 16,59 kg/ha in Hong Kong, 13,07 kg/ha in China, and 11,76 kg/ha in Japan [11].

\section{Biofungicides as alternative to synthetic fungicide control of plant diseases: uses, prospects and challenges}

One of the major problems of agriculture is plant diseases, which cause great economic damage as well as adversely affect human health.

There is a lot of information in the history of agricultural science about the tragic consequences of mass infestation of crops with diseases. Such catastrophic consequences are rarely observed in present times due to the availability of modern, more reliable methods of protection of plants from the mass development of diseases (epiphytotics) in a particular area, but plant diseases are still causing great damage to agriculture today. For example, the development of phytophthora may result in the loss of half or more of the potato crop, while the tomato may not yield at all under its damage. Due to rust diseases of wheat and other grain crops, in most cases $30-40 \%$ of the crop is lost, and $10-15 \%$ of crop due to powdery mildew. A lot of vegetable products are lost because of the diseases infestation. The damage of phytopathogenic organisms appears to be direct and indirect. The damage of a phytopathogen measured by direct and indirect loss is not limited to a decrease in sales income. There are such plant diseases with which the use of an infected product poses a danger to humans and farm animals. For example, some fungi belonging to the genus Fusarium, which grow on the grains of cereals, poison flour and bread made from it. Ergot, fusarium, and some other diseases can cause animal poisoning too [12].

If crops are not reliably protected from disease, the efficacy of agricultural activities will be minimal and the economy will be severely damaged. The farming system in the condition of intensive agriculture cannot be implemented without the application of well-organized protective measures and practices. The most effective and proper measures in terms of environmental protection is integrated protection of plants, which does not intend completely to eliminate mechanically the individual species of pests, but focuses on keeping their level low and minimizing adverse effects on the environment. 
Today, about $83 \%$ of the known infectious diseases of plants is caused by fungi, $9 \%$ by virus and more than $7 \%$ by bacteria. It is impossible to imagine the development of agriculture without human intervention. They use pesticides against harmful organisms for plants, i.e, herbicides against weeds, fungicides against diseases, insecticides against pests and insects. These pesticides can have both chemical synthesis and biological origin [13].

In recent years, much attention has been paid to ecologically pure biological control measures against plant diseases as an alternative to conventional chemical fungicides [14]. Today, more than 40 types of biological preparations are produced in the world [15]. One of the most promising new trends of protection of agricultural crops from phytopathogens is to increase the induction of plant resistance to pathogens and adverse environmental factors using these biopreparations [16].

The biological method of protecting plants from pathogen microorganisms is based on the use of antagonistic microorganisms. To date, a number of microorganisms have been identified that have antagonistic effects on phytopagenic fungi. They include Bacillus, Candida, Lactobacillus, Pseudomonas, Streptomyces and other antagonists $[14]$.

Biofungicides are the common name for preparations derived from microorganisms and their vital products and used against plant diseases [17]. Due to their biological origin and very low concentrations of active substances, most of the preparations in this group are considered to be ecologically pure. In addition to having minimal toxicity, these products have a wide range of effects on various pathogens, as well as increase the resistance of plants to adverse factors, and appear to be cheaper [18].

Biofungicides are produced in the form of wettable powder, emulsion concentrate, suspension concentrate, tablets and other forms. There are general requirements for each manufactured biopreparation and they should be standard. The titer of the preparation (concentration or number of virulent spores per $1 \mathrm{~g}$ or $1 \mathrm{ml}$, the number of colony-forming units) should be constant. The titer of the preparation, i.e the number of spores, crystals or the number of colony-forming units, is determined with a microscope in Goryaeva chamber.

Biofungicides are applied by treating planting material, adding to the soil and spraying the growing plant [19]. A number of foreign and domestic biofungicides are used in agricultural production of Russian Federation, including Bio-fugus (Trichoderma spp., Belgium), Binab-T (Trichoderma harzianum and T. polysporum, Sweden), Biotrek (T. harzianum, USA), Serenada, Kodiak (Bacillus subtilis, USA), Rhizo-plus (B. subtilis, Germany), Baktofit, Phytosporin (B. subtilis, Russia), Phytolavin (Streptomyces griseus, Russia), Planriz (Pseudomonas fluorescens, Belarus and Russia) [20, 21].

Ohio State University and University of Massachusetts Amherst Extension Center in the USA recommended a number of biopesticides against the diseases of agricultural crops to the farmers who are producing organic product (Table 2) $[22,23]$.

A number of scientific studies and research in the Republic of Uzbekistan, have been conducted on the use of biological preparations against plant diseases, including research work of Kh. Tillaev [24, 25, 26], A. Khakimov [27, 28], A.Khakimov et al [29], E.A. Kuziev [30] and N. Tillakhodjaeva [31, 32].

Several biofungicides were registered by the State Chemical Commission and approved for use in Uzbekistan, they are currently used against diseases of cotton, tomato, cucumber and other plants (Table 3) [33].

Although a number of advantages of fungicides of biological origin have been mentioned above, of course, they also have some disadvantages. These include their lack of rapid response to phytopathogenic organisms, their intolerance to temperature regimes, and the need to re-apply them to obtain high efficiency [34, 35].

Today, not only in our country, but also in the world, the production of biological means for plant protection further enhances interest due to the fact that they are really natural and ecologically pure products, safe for human health, minimum level of resistance of pests to these preparations and many other advantages.

Utilization of synthetic chemicals causes soil contamination and has an impact on the food chain. Moreover, the establishment of standards by international experts, expands the focus on the cultivation of organic fruits and vegetables. This, in turn, will lead to an increase in the use of biopesticides in the future. The global market for biopesticides production is expected to grow by $14.7 \%$ to $\$ 4.3$ billion in 2020 and reach $\$ 8.5$ billion by 2025 [36]. The global biofungicides market is estimated to account for a value of USD 1.6 billion in 2020 and is projected to grow at a CAGR $16.1 \%$, to reach a value of USD 3.4 billion by 2025. Key players in the biofungicides market include BASF SE 
Table 2 Microbial biopesticides for the control of plant pathogens in USA*

\begin{tabular}{|c|c|c|}
\hline Trade name & Biocontrol Organism & Diseases or target organism \\
\hline Actinovate & Streptomyces lydicus & $\begin{array}{c}\text { Powdery mildew, Downy mildew, Botrytis, } \\
\text { Rhizoctonia, Pythium, Phytophthora, } \\
\text { Fusarium, Verticillium }\end{array}$ \\
\hline BotryStop & Ulocladium oudemansii U3 & Botrytis, Sclerotinia \\
\hline Cease, Rhapsody & Bacillus subtillis QST 713 & Rhizoctonia, Pythium, Phytophthora, others \\
\hline Companion Liquid & Bacillus subtillis GB03 & $\begin{array}{c}\text { Leaf spots, Powdery mildew, Botrytis, } \\
\text { bacterial diseases, Rhizocotonia, Pythium, } \\
\text { Phytophthora }\end{array}$ \\
\hline Contans WG & Coniothryium minitans & Sclerotinia sclerotiorum, S. minor \\
\hline Double Nickel, Triathlon & Bacillus amyloliquefaciens & $\begin{array}{l}\text { Powdery mildew, Downy mildew, Botrytis, } \\
\text { Rhizoctonia, Pythium, others }\end{array}$ \\
\hline Galltrol & $\begin{array}{c}\text { Agrobacterium radiobacter } \\
\mathrm{K} 84\end{array}$ & Agrobacterium tumefaciens \\
\hline MycoStop & Streptomyces griseoviridis & $\begin{array}{l}\text { Botrytis, Rhizoctonia, Pythium, } \\
\text { Phytophthora, Alternaria }\end{array}$ \\
\hline $\begin{array}{l}\text { Plant Shield, Root Shield, } \\
\text { T-22 Planter Box }\end{array}$ & Trichoderma harzianum & $\begin{array}{c}\text { Rhizoctonia, Pythium, Fusarium, } \\
\text { Cylindrocladium, Thielaviopis }\end{array}$ \\
\hline Prestop WP & $\begin{array}{c}\text { Gliocladium catenulatum } \\
\text { JII } 446\end{array}$ & $\begin{array}{c}\text { Botrytis, Rhizoctonia, Pythium, } \\
\text { Phytophthora, Fusarium, Verticillium }\end{array}$ \\
\hline SoilGard & Gliocladium virens GL-21 & Rhizoctonia, Pythium \\
\hline AgriPhage & $\begin{array}{c}\text { Bacteriophages of } \\
\text { Xanthomonas spp. and } \\
\text { Pseudomonas syringae pv. } \\
\text { tomato }\end{array}$ & $\begin{array}{l}\text { Bacterial spot in pepper and tomatoes and } \\
\text { bacterial speck in tomatoes }\end{array}$ \\
\hline $\begin{array}{l}\text { Bloomtime Biological } \\
\text { FD3 }\end{array}$ & $\begin{array}{c}\text { Pantoea agglomerans strain } \\
\text { E325 }\end{array}$ & Fireblight (Erwinia amylovora) \\
\hline Ballad Plus Biofungicide & Bacillus pumilus QST 2808 & $\begin{array}{l}\text { Rust, powdery mildew, Cercospora and } \\
\text { brown spot }\end{array}$ \\
\hline $\begin{array}{l}\text { Kodiak Concentrate } \\
\text { Biological Fungicide }\end{array}$ & Bacillus subtilis GB03 & $\begin{array}{c}\text { Rhizoctonia, Fusarium, Alternaria, } \\
\text { Aspergillus and others that attack the root } \\
\text { systems of plants }\end{array}$ \\
\hline $\begin{array}{l}\text { Serenade Wettable } \\
\text { Powder Biofungicide }\end{array}$ & Bacillus subtilis strain QST 713 & $\begin{array}{l}\text { Fire blight, Botrytis, sour rot, rust, } \\
\text { Sclerotinia, powdery mildew, bacterial spot }\end{array}$ \\
\hline
\end{tabular}

Table 3 List of biological fungicides allowed to be used in Uzbekistan

\begin{tabular}{|c|l|c|c|}
\hline No & \multicolumn{1}{|c|}{ Biological fungicide } & Content of biological preparation & Manufacturer \\
\hline 1. & ORGAMIKA C, L. & $\begin{array}{c}\text { Bacillus amyloliquefaciens BKПM B-12464, } \\
2 \times 10^{8} \mathrm{CFU} / \mathrm{ml}\end{array}$ & Russian Federation \\
\hline 2. & PSEVDOPAKTERIN 3, L. & $\begin{array}{c}\text { Pseudomonas aureofaciens } \\
\text { B-2391, } 2 \times 10^{9} \mathrm{CFU} / \mathrm{ml}\end{array}$ & Russian Federation \\
\hline 3. & KAZUMIN 2 L, WS & Streptomyces kasugaensis, $20 \mathrm{~g} / \mathrm{l}$ & Japan \\
\hline 4. & ORGAMIKA F, L. & $\begin{array}{c}\text { Trichoderma asperellum, } \\
\text { BKחM F-1323, } 2 \times 10^{8} \mathrm{CFU} / \mathrm{ml}\end{array}$ & Russian Federation \\
\hline 5. & SPORAGIN, WSC & Bacillus subtilis, pcs. AN $2004,1500 \mathrm{AU} \backslash \mathrm{g}$ & Uzbekistan \\
\hline 6. & BIST, SC & Pseudomonas putida Pp-1, $0,8-1,0 \mathrm{bln} . / \mathrm{ml}$ & Uzbekistan \\
\hline 7. & TRICHODERMIN, WP & Trichoderma viride $\mathrm{H} 13,6 \times 10^{9} \mathrm{CFU} / \mathrm{ml}$ & Russian Federation \\
\hline 8. & FITOLAVIN, WSC. & $\begin{array}{c}\text { Antibiotic complex of Fitobacteriomicyn } \\
\text { streptotricyn, } 120000 \mathrm{AU} / \mathrm{ml}(32 \mathrm{~g} / \mathrm{l})\end{array}$ \\
\hline
\end{tabular}

Note: L-liquid, WS- Water solution, WSC- Water-Soluble Concentrate, SC-Suspension concentrate, WP-Wettable powder, CFU- Colony-forming unit, AU- Activity unit. 
(Germany), Bayer AG (Germany), Syngenta AG (Switzerland), FMC Corporation (US), Nufarm (Australia), Novozymes (Denmark), Marrone Bio Innovations (US), Koppert Biological Systems (Netherlands), Isagro S.P.A (Italy), T. Stanes \& Company Limited (India), BioWorks (US), The Stockton Group (Israel), Valent Biosciences (US), Agri Life (India). Certis U.S.A (US), Andermatt Biocontrol AG (Switzerland), Lesaffre (France), Rizobacter (Argentina), Vegalab S.A (US), Biobest Group NV (Belgium), and Biolchim (Italy) [37].

The market of biopesticides, including biofungicides, is developing in a low rate in Uzbekistan, and the use rate of biofungicides in the cultivation of agricultural crops is not high enough. It is obvious from Table 3, the "List of chemical and biological control means, defoliants and plant growth regulators approved for use against plant pests, diseases and weeds in agriculture of the Republic of Uzbekistan" contains 8 biofungicides, most of which are imported biofungicides.

\section{Conclusion}

The careless, irrational and improper use of synthetic pesticides can lead to soil contamination with pesticides, the emergence of extremely high resistance of pests, a sharp increase in the amount of pesticide residues in food products, the destruction of beneficial organisms and, most importantly, considerable harm to human health. To prevent such cases, it is necessary to use synthetic pesticides only when the pest exceeds the economic threshold, or to replace synthetic pesticides with biological preparations obtained on the base of substances of biological origin based on microorganisms, microbial producers and colony-forming units.

Today in our country, in the establishment of enterprises producing local biopreparations for agriculture, the development of a state program in this regard, and the financing of these projects is one of the most important issues, which requires, first of all, systematic research accordingly. This, in turn, serves as a great opportunity for local producers to develop their business, and the production of biological plant protection products in the Republic is a promising area. Of course, the first object for producers of biopesticides, as well as biofungicides, is to create strains of local microorganisms. Accordingly, it sets great responsibilities in this regard on the scientific communities and scientists.

\section{Compliance with ethical standards}

\section{Acknowledgments}

The authors, express their gratitude to Professors Batyr Khasanov, Mirakbar Zuparov and Riskibay Gulmurodov and leadership staff of the Tashkent State Agrarian University (Tashkent, Uzbekistan).

\section{Disclosure of conflict of interest}

No conflict of interest declared.

\section{References}

[1] Global trade in food and agricultural products more than doubles in last two decades. C2020 [23 September 2020]. Available from: http://www.fao.org/news/story/en/item/1309369/icode/

[2] FAO launches 2020 as the UN's International Year of Plant Health. (C2019 [2 December 2019]. Available from: http://www.fao.org/news/story/en/item/1253551/icode/

[3] Global pact against plant pests marks 60 years in action. FAO celebrates 60 anniversary of signing the International Plant Protection Convention. (C)2012 [3 April 2012]. Available from: http://www.fao.org/news/story/ru/item/132027/icode/

[4] Agrios GN. Plant pathology. San Diego: Academic Press; 2005.

[5] Lernoud J, Willer H. Organic Agriculture Worldwide 2017: Current Statistics. February 13, 2019. Nuremberg, Germany, BIOFACH; 2019.

[6] Morgera E, Caro CB, Durán GM. Organic agriculture and the law. FAO legislative study. Food and Agriculture Organization of the United Nations; 2012.

[7] Abhilash PC, Singh N. Pesticide use and application: anIndian scenario. Journal of Hazardous Materials, 2009; 165(1-3): 1-12. https://doi.org/10.1016/j.jhazmat.2008.10.061 
[8] Tilman D, Cassman KG, Matson PA, Naylor R, Polasky S. (2002). Agricultural sustainability and intensive production practices. Nature, 2002; 418 (6898) 671-77. https://doi.org/10.1038/nature01014

[9] Zhang W. Global pesticide use: profile, trend, cost/benefit and more. Proceedings of the International Academy of Ecology and Environmental Sciences, 2018; 8(1): 1-27.

[10] FAO statistics. (2019). http://www.fao.org/faostat/en/?\#data/RP

[11] Roser M. (2019). Pesticides. Published online at OurWorldInData.org. @2019. Available from: https://ourworldindata.org/pesticides

[12] Khasanov BO. Diseases of agricultural crops and their controlling measures. Tutorial for master students. Publ. house of TSAU; 2010.

[13] Pavlovskaya NE, Gagarina IN, Borodin DB, Gneusheva IA, Gorkova IV, Solohina IYu, Kostromicheva EV, Lushnikov AV, Yakovleva IV, Ageyeva NYu. Agrobiological substantiation of the technology of growing vegetable products with the use of biological means of protection: monograph. Orel: Publ. FSBEI HE Orlovo SAU; 2018.

[14] Azizbekyan RR. Use of spore-forming bacteria as biological plant protection products. Biotechnology. 2013; 1: 69-77.

[15] Golosova MA. Microbiological plant protection: Tutorial for students of specialty. Moscow: MSUF; 2003.

[16] Elad Y, Freeman S. (2002). Biological control of fungal plant pathogens. The Mycota XI Agricultural Applications. Ed. Kempken. Springer Verlag, Berlin Heidelberg; 2002; p. 93-109.

[17] Roger F, Keinath A. Biofungicides and chemicals for managing diseases in organic vegetable production. Clemson University Cooperative Ext. Information Leaflet 88. (C)2010. Available from: http://www.clemson.edu/psapublishing/PAGES/PLNTPATH/IL88.pdf

[18] Zlotnikov AK. Development and complex characteristics of poly-functional preparation Albit for plant protection from diseases and stress. [DSc dissertation]. Voronej; 2012.

[19] Cheremesin AI, Yakimova IA. Influence of plant growth stimulants and biofungicides on the productivity of potato microplants. Achievements of science and technology of the agro-industrial complex. 2011; 3: 26-28.

[20] Dyakunchak SA, Koroleva SV. Cabbage fusarium and its control measures. Agro XXI agro-industrial portal. Newspaper Plant protection. 2006; 2: 19-21.

[21] Kolomiyets EI, Romanovskaya TV, Zdor NA. Biopreparations - as an alternative to chemicals. Plant protection and quarantine. 2006; 10: 18-20.

[22] Cao C, Park S, McSpadden Gardener B. Biopesticide Controls of Plant Diseases: Resources and Products for Organic Farmers in Ohio. Ohio State University Extension, SAG-18 Agriculture and Natural Resources, Jun 25, 2010. (C)2010. Available from: https://ohioline.osu.edu/factsheet/SAG-1

[23] Dicklow MB. Biofungicides. Published on Center for Agriculture, Food and the Environment, The UMass Center for Agriculture, Food and the Environment is the home of UMass Extension and the Mass. Ag. Experiment Station. 2014. Updated by Angela Madeiras, 7/2018. (C)2018. Available from: https://ag.umass.edu/greenhousefloriculture/fact-sheets/biofungicides

[24] Tillaev KhT. Fungi of trichoderma genus against cotton wilt in Fergana valley. Materials from All-union symposium on Control of cotton wilt. Tashkent, 1964; p. 152-153.

[25] Tillaev KhT. Trichoderma efficiency in the control of wilt. Cotton growing, 1980; 12: 19-20.

[26] Tillaev KhT. Trichoderma - wilt fighting fungus. Tashkent, Mehnat, 1989.

[27] Khakimov AKh. Results of the study by SARIPP on the use of trichoderma against verticillium. Central-Asian Research Institute of Plant Protection, 1981; B5: 91-94.

[28] Khakimov A. Spread of plant diseases in greenhouse condition and their controlling measures. Assistance to lecturer. Tashkent, Bilim society, 1991.

[29] Khakimov AKh, Ubaydullev KhKh, Sarimsakova RK. Book: The use of trichoderma in cotton growing. Tashkent, Fan, 1982.

[30] Kuziev EA. Most harmful fungal diseases of white cabbage in Tashkent oasis and measures on limiting their development. [PhD dissertation (Candidate of agricultural sciences)]. Kiev; 1992. 
[31] Tillakhodjaeva NR. Biological efficiency of biopreparation trichodermin against fusarium wilt of cotton. Bulletin of the agrarian science of Uzbekistan, 2016; 3(65): 69-72.

[32] Tillakhodjaeva NR. Restoration of the natural balance of soil microorganisms by the bio-method. Bulletin of the agrarian science of Uzbekistan, 2017; 1(67): 86-88.

[33] Amendments on "List of chemical and biological control means, defoliants and plant growth regulators approved for use against plant pests, diseases and weeds in agriculture of the Republic of Uzbekistan". Tashkent, «Niso poligraf» LLC; 2018.

[34] Gavrilova AYu, Frolova SA, Borodin DB. Study of the effect of pesticides of biological origin on the onset of phenological phases of potatoes. In the collection: Plant genetic resources - the basis of selection and seed production in the development of organic agriculture. Materials of the All-Russian Scientific and Practical Conference. 2018; p. 60-64.

[35] Logvinova TS, Bulgakova VP. Production and use of biological protection means in Russia and in the world. Innovations in nature management and environmental protection. Materials from the I National scientific and practical conference with international participation. Saratov, January 23-24, 2019; p.546-551.

[36] Biopesticides Market. Biopesticides Market by Type (Bioinsecticides, Biofungicides, Bionematicides, and Bioherbicides), Source (Microbials, Biochemicals, and Beneficial Insects), Mode of Application, Formulation, Crop Application, and Region - Global Forecast to 2025. (C2020 [June, 2020]. Available from: https://www.marketsandmarkets.com/PressReleases/biopesticide.asp

[37] Biofungicides Market by Type (Microbial species, Botanical), Mode of Application (Soil treatment, Foliar application, Seed treatment), Species (Bacillus, Trichoderma, Streptomyces, Pseudomonas), Crop Type, Formulation, and Region - Global Forecast to 2025. (C2020 [May, 2020]. Available from: https://www.marketsandmarkets.com/Market-Reports/biofungicide-market-8734417.html 